\title{
Information sources for leprosy, with particular reference to developing countries*
}

\author{
LINDA DORRINGTON \\ Cairns Library, John Radcliffe Hospital, Headington, Oxford \\ OX3 9DU
}

Received for publication 5 July 1981

\begin{abstract}
Summary A brief description is given of the library and information sources available to developing countries, with particular reference to Latin America, South-east Asia and Africa. The role of WHO in the on-going provision of literature services is reviewed. Four appendices deal with on-line service suppliers, directories of libraries and information services, a glossary of terms, and references to published work on libraries and information systems.
\end{abstract}

\section{Introduction}

Developing countries are often in the anomalous position of being almost totally dependent on information sources published by countries in Europe and North America, and on outside agencies to provide the kind of information service they themselves would like to offer their patrons.

Development of information services in the Third World, Asia, Africa and Latin America, has not been solely reliant on economic factors. Those countries which have strong ties with developed countries often have good information services despite their apparent lack of wealth, especially in India and Africa, where the links made with Great Britain during colonial times are still maintained by many libraries. The reliance of these countries on aid and support to finance the building, staffing and stocking of libraries has led to an unevenness of service from which national and international agencies such as the National

* This article, with particular reference to developing countries, has been abridged and adapted from one of considerably greater length, which contains further information on the use of libraries in the UK and elsewhere, which may be of interest to those who are not familiar with the services available. Copies may be obtained from the author at the address above. Editor 
Library of Medicine (NLM) and the WHO have emerged as life-lines for the continuing expansion of information services.

The last decade has seen a radical rethinking of policies and commitments to information services by the introduction of a global information network (GIN) to provide different user groups everywhere access to the world's store of scientific knowledge. The leader in this field was UNESCO, which set up UNISIST (World Science Information System) in 1971, leading to the establishment of NATIS (National Information Systems) in 1974. The United Nations and other international agencies, particularly ICSU (International Council of Scientific Unions), have been responsible for the founding of numerous international information systems. The Directory of UN Information Systems and Services lists some $30 \mathrm{UN}$ agencies responsible for more than 100 information systems of which three-quarters relate to science and technology.

The three areas of library services with which libraries in developing countries are most concerned are the acquisition of stock, document delivery and access to the world's published literature in the form of indexes and abstract journals.

The high cost of books and journal subscriptions, and the physical effort taken to acquire them are two of the reasons why collections in the majority of libraries are small and out of date. Time is the greatest factor where document delivery is slow and costly, and many libraries have to rely on national and international agencies for the supply of literature searches, photocopies and original documents. One such agency is the NLM's international services. The NLM supplies such publications as Index Medicus and Abridged Index Medicus to nearly 400 libraries in 70 countries in exchange for periodicals and monographs issued by foreign medical institutions that could not be easily obtained by the NLM otherwise. Some $15 \%$ of its photocopy requests come from outside the United States, and under the US Agency for International Development (AID) programme it provides MEDLINE searches and subscriptions to Index Medicus to libraries mostly in Latin America and South-east Asia.

A joint project with WHO is the publication of the Quarterly Bibliography of Major Tropical Diseases, which lists citations from MEDLARS on research and treatment relating to filariasis, leishmaniasis, leprosy, malaria, schistosomiasis and trypanosomiasis.

\section{Latin America}

Pan American Health Organization (PAHO). Following a study of biomedical communications in Latin America by PAHO, with the NLM acting as an adviser, a recommendation was made to establish a regional library of medicine in . South America. Thus the Bibliotheca Regional de Medicina (BIREME) was founded in 1965, based on the library of the Escola Paulista de Medicina, 
Sau Paulo, Brazil. Funding was jointly given by the Ministries of Health and Education in Brazil, the PAHO, the Commonwealth Fund and the Kellogg Foundation, and today BIREME's annual budget is provided by PAHO, WHO and other external sources in Brazil and South America. The NLM continues to act as adviser and still supplies photocopies, serials and books exchange and literature searches. BIREME has recently undertaken to develop specialized audio-visual and computer-based reference services using a subset of the NLMMEDLARS database. BIREME also provides reference services, specialized bibliographies, interlibrary loans and library staff training not only within Brazil but to other South American countries.

Owing to the lack of Latin American material in Index Medicus, 1979 saw the publication of the first issue of Index Medicus Latino Americano by BIREME, covering 250 journals out of approximately 800 published in South America. Only 44 Latin American titles are covered by Index Medicus .

\section{South-east Asia}

The South-east Asia Medical Information Centre (SEAMIC) began in 1973, funded by the International Medical Foundation of Japan to assist South-east Asian countries in health planning, medical care and the exchange of medical and health information and materials. Currently, work is progressing on the establishment of a health literature network based on the developed countries in this region, such as Australia and Japan, to provide document and support services to libraries and health centres in South-east Asia.

\section{Asia and Africa}

Many medical libraries in India and Africa have close ties with libraries in Great Britain, especially through such agencies as the British Council. Some of the librarians have been trained at library schools in Britain and British medical librarians lecture at and advise library schools and libraries in these continents. The majority of medical libraries in Africa are part of the various countries' medical schools but are at different stages of development. The commitment to provide adequate library and information services varies from country to country and even amongst libraries within the same country.

The WHO plan for Africa does not envisage the creation of a single regional medical library as in Latin America, or a single regional network as in Southeast Asia, but the development of a national network based on three regional health literature centres, one each for the English-, French-, and Portuguesespeaking countries. At the moment it is WHO which provides the literature services necessary for continued medical research in these continents. 


\section{World Health Organization}

In 1972 WHO began operating a MEDLARS service using a batch retrieval programme, switching to on-line searching in 1974 by using the TYMSHARE network to access the MEDLARS service of the NLM. The service is available to all the WHO member states in Asia, Africa and Oceania. The WHO search service is backed up by a document delivery service, supplying photocopies of relevant journal articles, although there is a considerable time lag between request and receipt of the items. To aid librarians and users, a newsletter on health literature topics is sent to all users of the WHO MEDLINE Centre, and covers such topics as WHO library activities, a glossary explaining technical terms used in information retrieval, guidance on how to complete a search request form, and so on. In addition to MEDLINE, access to a wide range of other databases from SDC and DIALOG is available.

In 1977 the NLM terminated its agreement with WHO to provide on-line access from Geneva. Instead the WHO Regional Offices in developing countries without a regional medical library network undertake the fulfilment of search requests.

The WHO involvement in the Index Medicus Latino Americano has already been mentioned. Another project being undertaken is the possibility of publishing three regional editions of Index Medicus for Africa, the eastern Mediterranean and South-east Asia, in conjunction with the Rockefeller Foundation.

WHO are also planning to sponsor a Health-Related Information System (HERIS), which will provide essential information, generated by or specifically for developing countries, to health planners and health care administrators who are involved in the development of national programmes and services to achieve the WHO aim of 'Health for All by the Year 2000'.

\section{The Future}

Developments and research in the field of new technology will bring about radical changes in the use of computers and computing systems. Work is progressing on full-text retrieval systems, whereby the whole text of a document is stored in a computer and can be retrieved instead of just the bibliographic details. Computers lend themselves easily to the storage and display of data, so that graphics and figures can be easily manipulated by a computer program. Computer storage media such as video discs will enable much more information to be stored on-line, and as costs recede more in-house information retrieval systems will become commonplace. As telecommunication systems become more sophisticated and computer hardware cheaper to produce, retrieval systems of all types should become more widely available in both the home and work environments. 
On-line document delivery and on-line book ordering are new concepts that will become more widely available, whereby documents can be ordered on-line at the terminal following the retrieval of the selected references. The database service suppliers are already using document delivery for journal articles by passing on the order to the database supplier, who processes the request and dispatches either a photocopy of the journal article or a copy of the original document.

In a field which is expanding so rapidly and which is full of perplexing technology, it is becoming increasingly difficult for those who seek information from library services to appreciate the potential. Some of the more important terms, sources of information and references are included here in the form of appendices, but the basic principle to follow is to seek the help and advice of trained library staff, who are willing and able to guide an enquirer through the mass of information.

\section{Appendix 1. Online service suppliers address list}

Blaise Marketing

2 Sheraton Street

London W1V 4BH, England

Dimdi

Weisshaustrasse 27

Postfach 420580

D-5000 Köln 41

Federal Republic of Germany

\section{ESA-IRS}

Department of Industry

Technology Reports Centre

Orpington

Kent BR5 3RF, England

SDC Search Service

2500 Colorado Avenue

Santa Monica

California, USA 90406
Data-Star

199 High Street

Orpington

Kent BR6 OPF, England

Dialog Information Services Inc. 3460 Hillview Avenue

Palo Alto

California, USA 94304

or European Space Agency

ESRIN/IRS

Via Galileo Galilei

Frascaitti

Italy

BRS Inc.

1462 Erie Boulevard

Schenectady

New York, USA 12305 


\section{Appendix 2. Directories of Libraries and Information Services}

MEDICAL

Directory of Health Sciences Libraries in the United States 1979. Compiled and edited by A M Rees and S Crawford, Case Western Reserve University, Cleveland Health Sciences Library, Cleveland, Ohio. Chicago, Illinois, Medical Library Association, 1980.

Directory of Major Medical Libraries Worldwide. US Directory Services. Miami, Florida, US Directory Service, 1978.

Directory of Medical Libraries in the British Isles. 4th ed. London, Library Association, 1976. (Fifth edition in preparation.)

\section{GENER A L}

American Library Directory. 33rd ed., New York, Bowker, 1980.

Directory of Documentation, Libraries and Archive Services in Africa. Paris, UNESCO, 1977.

Directory of East African Libraries. 2nd revised edition by M E C Kibwuka-

Bagenda, T K Lwanga and G A Thomspon. Kampala, Makerere University

College Library, 1969.

Directory of Libraries and Documentation Centres in the United Nations System. Geneva, United Nations Library, 1979.

Directory of Libraries and Information Services, by the Sierra Leone Library Association. Freetown, the Association, 1976.

A Directory of Libraries and Information Sources in Hawaii and Pacific Islands.

Revised edition by A D C Luster. Hawaii, Hawaii Library Association, 1977.

Directory of Libraries in Botswana. Compiled by L B Mushonga. Gaborone, Botswana, National Institute for Research in Development and African Studies, Documentation Unit, 1977.

Directory of Libraries in Ghana. Compiled by A Nitecki. Legon, Department of

Library and Archival Studies, University of Ghana, 1974.

Directory of Libraries in Kenya. Compiled and edited by J R Njuguna. Nairobi, Gazelle Books, 1977.

Directory of Libraries in Singapore. Compiled by L U Wen Lim, YL Wicks and J Neo. Singapore, Library Association of Singapore, 1975.

Directory of Libraries in Tanzania. Dar es Salaam, Tanganyika Library Service, 1972.

Directory of Malawi Libraries. Edited by S M Made and T M Brown. Zomba, Malawi, Chancellor College, 1976.

Directory of Research and Special Libraries in India and Sri Lanka. Edited by N Chatterjee. Calcutta, Information Research Academy, 1979.

Directory of Special Libraries and Information Centres. 5th ed. 3 volumes.

Edited by M. L. Young. New York, Gale, 1979. 
Directory of Special Libraries in Malaysia. Compiled by the Persatuan Perpustakaan Standing Committee on Special Libraries. Kuala Lumpar, Persatuan Perpustakaan Malaysia, 1976.

Directory of Swaziland Libraries. Edited by A W Z Kuzwayo and M Ward. Roma, Lesotho, University of Botswana, Lesotho and Swaziland, Swaziland Campus Library, 1975.

IFLA [International Federation of Library Associations] Directory, 1979. New York, K G Saur, 1978.

Major Libraries of the World. Edited by C R Steele. New York, Bowker, 1976.

\section{Appendix 3. Glossary}

Abstract: A summary of the content of a publication, usually an article in a periodical, with full bibliographic details of the source journal.

Batch processing: A technique of processing computer data by collecting the items into a group and running it at the most economic time, as opposed to on-line processing.

Bibliography: A list of books or other publications. Many kinds are available, national, international, comprehensive, selective, subject, historical, cumulative, personal, etc. In some bibliographies entries are arranged in a classified order by subject with separate author and title lists. In others, author, title and subject are arranged in one alphabetical sequence.

Database: A collection of data held in a machine-readable form, typically on magnetic discs. A bibliographic database stores bibliographic records.

Database supplier: The organization responsible for the creation of a machinereadable file.

Index: An alphabetical list of the contents of journals and books usually arranged by subject, but may also include author and subject lists. An indexing journal identifies articles on given subjects which have appeared in a wide range of journals. It gives bibliographic details but does not elaborate on the contents.

Information retrieval: The finding of documents, or the information contained in documents, in a library, selectively recalling recorded information.

Intermediary or search analyst: The person, either a librarian or information scientist, who carries out on-line searches on behalf of the requester, and who is an expert on searching techniques, database structure, etc.

Keypad: A keyboard containing the characters $0-9$ and $*$ used to access a viewdata system.

Modem: Modulator/Demodulator. Converts a digital signal into a signal suitable for telephone transmission and vice versa.

Network: Telecommunication. A telephone network allowing access to computer systems throughout the world via the public telephone system. 


\section{Linda Dorrington}

Off-line: Mode of operation in which terminals or other equipment can continue to operate whilst disconnected from a central processor. Contrasted with on-line.

On-line: Mode of operation in which terminals or other equipment, are controlled by a central processor. Contrasted to off-line .

On-line service suppliers or spinners: The organization responsible for gathering together various databases, creating a program by which the databases can be searched and offering the service as a package to libraries and information centres.

Packet-switching: A technique for transmitting data packets through a telecommunications network.

Password: A (secret) identification number keyed by the user and checked by the system before permitting access to the database.

Record: A complete set of bibliographical information referring to a particular item in a machine-readable file.

Reference: A bibliographic reference or citation is a set of data describing and identifying a particular publication, such as an article in a journal or a chapter in a book, to enable the original document to be located.

Search strategy: The selection of terms and formulation of a strategy to link the terms, using the operators OR or AND to retrieve references on a given topic.

Terminal: A device used to communicate information to and from a computer system. It can be wired directly to a computer or used through a network at some distance from the system.

Thesaurus: A list of pre-determined and acceptable index terms. It is used to define a subject or aspects of a subject where synonyms may present problems.

Videotex: The CCITT (Comité Consultatif International Télégraphique et Téléphonique) approved name for narrow-band interactive services such as Viewdata.

Viewdata: A generic term to describe a service for channelling information from information providers to users via the public telephone system and a television set.

\section{Appendix 4. Bibliography}

The following list is a combination of the major sources consulted for this paper and items for further reading.

Adimorah ENO. Problems of scientific information work in developing countries. The Information Scientist 1976; 10(4): 139-48.

Agarwal SN. Bio-medical information system in India \& USA; with special reference to the role of National Library of Medicine of USA. Lucknow Librarian 1980; 12(2); 59-66. 
Atherton P. Handbook for information systems and services. Paris: UNESCO, 1977.

Beatty WK. Searching the literature and computerized services in medicine: guides and methods for the clinician. Ann Intern Med 1979; 91(2): 326-32.

Botelho TMG. ARUANDA - an on-line information system throughout Brazilian cities. In: Tally RD, Deultgen RR, eds. Information choices and policies. Proceedings of the 42nd ASIS Annual Meeting, October 14-18, 1979. Vol. 16. White Plains, NY: Knowledge Industry Publications, Inc, 1979: 15-23.

Bourne CP. Computer-based reference services as an alternative means to improve resourcepoor local libraries in developing countries. Int Lib Rev 1977; 9(1): 43-50.

Carmel M. ed. Medical librarianship. London, Library Association, 1981.

Dean J. Information service in the development of poor nations. In: Library Association of Australia Proceedings of the 18th Biennial Conference, 23-29 August, 1975. Melbourne, LAA, 1976: 408-19.

Deunette JB, com. UK Online Search Services, London: Aslib, 1981.

Doszkocs TE, Rapp BA, Schoolman HM. Automated information retrieval in science and technology. Science 1980 April 4; 208 (4439): 25-30.

Eusidic Database guide 1981. Oxford: Learned Information, 1980.

Hall JL. On-line information retrieval sourcebook. London: Aslib, 1977.

Harrod LM. The Librarians' glossary of terms used in librarianship, documentation and the book crafts. 4th rev. ed. London: Deutsch, 1977.

Henry WM, Leigh JA, Tedd LA, Williams PW. On-line searching: an introduction. London: Butterworths, 1980.

Holmes PL. The British Library automated information service (BLAISE). Aslib Proc 1977; 29(6): 214-20.

McCarthy C. Medical libraries in developing countries: an international approach. Int Lib Rev 1978; 10(4): 435-46.

McCarthy C. Third World medical libraries. In: Carmel M, ed. Medical librarianship. London: Library Association, 1981: 297-309.

Matthews DA, Picken FM. Medical librarianship. London: Bingley, 1979.

Munn RF. Appropriate technology and information services in developing countries. Int Lib Rev 1978; 10(1): 32-7.

Morton LT. How to use a medical library. 6th ed. London: Heinemann, 1979.

Polytechnic of the South Bank Library. Guide to literature searching in nursing and community health. London: The Polytechnic, nd.

Rowley JE. Computers for libraries. London: Bingley, 1980.

Saracevic T. Appropriate technology and appropriate information - expressions of needs from less developed countries (LDC's). In: Tally RD, Deultgen RR, eds. Information choices and policies. Proceedings of the 42nd ASIS Annual Meeting, October 14-18, 1979. Vol. 16. White Plains, NY: Knowledge Industry Publications, Inc, 1979: 91-7.

Saracevic T. Perception of the needs for scientific and technical information in less-developed countries. J Documentation 1980; 36(3): 214-67.

Saracevic T. ed. Selective libraries for medical schools in less-developed countries. A Bellagio Conference October 3-November 3, 1979. New York: Rockefeller Foundation, 1980.

Sardar Z. Between GIN and TWIN: meeting the information needs of the Third World. Aslib Proc 1981;33(2): 53-61.

Singh J. Library and health literature services of World Health Organization. Herald Lib Sci 1980 Jan-Apr; $19(1-2): 37-51$.

Stokes AV. Viewdata: a public information utility. 2nd ed. Langton Information Systems Ltd, 1980.

Taine SI. Health literature: a new world service (WHO). Hlth Welfare Lib Q 1974; 1(3): $63-4$. 


\section{Linda Dorrington}

Tedd LA. An introduction to computer-based library systems. London: Heyden, 1977.

Tell BV. The awakening information needs of the developing countries. J Inf Sci 1980; 1(5): 285-9.

US Department of Health and Human Services. Public Health Service. National Institutes of Health. National Library of Medicine Programs and Services Fiscal year 1980. Bethesda: NLM, 1981. (NIH Publication No. 81-256).

US Department of Health and Human Services. Introduction. Index Medicus 1981;22 (1 pt. 1): ix-xi.

Weitzel R. Medline services to the developing countries. Bull Med Lib Ass 1976; 64(1): 32-5.

Weitzel R. The library of WHO (Die Bibliothek der WHO). Med Bibl Dok 1977; 1(1): 30.

Williams ME. On-line retrieval - today and tomorrow. In: Proceedings of the First International On-line Information Meeting, London, 13-15 December, 1977. Oxford: Learned Information, 1977: 1-15.

Woodward AM. Future information requirements of the third world. J Inf Sci 1980; 1(5): 259-65.

Woolfe R. Videotex: the new television-telephone information services. London: Heyden, 1980.

World Health Organization. The work of WHO 1978-1979. Biennial Report of the DirectorGeneral to the World Health Assembly and to the United Nations. Geneva: WHO, 1980. 